\title{
8 History brought home: Post-colonial migrations and the Dutch rediscovery of slavery
}

\author{
Gert Oostindie
}

\subsection{Introduction}

Slavery and slave resistance have been core issues in the post-war historiography of the Caribbean. ${ }^{1}$ At the same time, massive migration from the British, Dutch and French Caribbeans to Europe has literally brought the legacies of colonialism and hence slavery home to the former metropolitan countries. Virtually all Caribbean nations, moreover, are thoroughly transnational today. One of the consequences of this post-colonial condition has been the emergence of what is now generally known as 'the Black Atlantic', a concept coined by Gilroy (1993). The shared history of enslavement provides a central point of reference within this Black Atlantic. It also provides inspiration for narratives of history that gloss over fundamental differences within the history of Atlantic slavery.

This chapter addresses the recent Dutch rediscovery and, at times, perhaps reinvention of the Netherlands' long history of slave trade and slavery in relation to the impact of the post-war migration from the Dutch Caribbean. A first issue is the overall impact of post-colonial migration from Indonesia and the Caribbean - on the way Dutch history is canonised. The next sections provide a succinct analysis of the significance of slave trade and slavery in the various realms of the Dutch colonial empire, followed by an analysis of the recent and relatively successful impact of the Caribbean demand to accept African slavery as an integral part of Dutch national history. The final sections discuss the contested issue of the legacies of slavery and the issue of 'black'-versus-'white' perspectives; question whether Black Atlantic interpretations indeed help us see New World slavery and its legacies with fresh eyes; debate the concept and uses of 'cultural trauma'; and, finally, offer some reflections on the position of historians.

A word regarding the background to this chapter is appropriate. Three Dutch historians of slavery have been particular vocal on these issues in the Netherlands and have therefore become voluntary or reluctant actors in the field at the same time. Emmer and Van Stipriaan, both highly respected for their scholarly work, have represented some strongly opposing views 
on these matters. A third historian engaged in these debates is the present author, who should probably be located somewhere between the other two. A good deal of this chapter therefore derives from publications by these three authors as well as from the present author's ongoing engagement with these issues. A good outsider's analysis is provided by Kardux. ${ }^{2}$

\subsection{A historical canon for a post-colonial metropolis}

World War II sparked the decolonisation of the Dutch empire and, even more unexpectedly to the Dutch, the first of a series of post-colonial migrations. The total number of immigrants from Indonesia in the 1945-1962 period is estimated at around 300,000. This figure is negligible in comparison to an Indonesian population of roughly one hundred million in the late 1940s, but involved the overwhelming majority from the circles where most of these immigrants originated, i.e. Dutch colonials and Indo-Dutch. Today, over half a million Dutch citizens have some Indonesian roots.

Whereas this first chapter of decolonisation thus caused unrepresentative and comparatively insignificant migration, the 1975 transfer of sovereignty to Surinam sparked an exodus involving colonial citizens of all classes, ethnicities and generations, a cross-section of the entire population. Over the next decades, the demographic growth of the Surinamese community would be a largely Dutch affair. Today, the country houses some 475,000 inhabitants, as against a Surinamese community of some 335,000 in the Netherlands. According to the 2004 Surinamese census, roughly half of the Surinamese population has African roots.

Large-scale Antillean migration to the Netherlands, mainly from Curaçao, dates from the late 1980s and beyond. Again, the numerical significance of the migration lies primarily on the islands themselves. This Antillean migration is not representative by origins, as the overwhelming majority hails from one island only. But again, in other dimensions the migrants form a cross-section of the insular population. The total population of the six islands is estimated at 280,000 . The Antillean community in the Netherlands in 2006 stood at 130,000. The great majority of the Antillean community in the Netherlands is of African origins.

With an estimated one million taken together, the share of Dutch citizens with colonial or post-colonial roots in the total population is considerable. The number of Dutch people with 'roots' in Indonesia is estimated at just over half a million; the number with Caribbean origins at just under half a million; the number of Dutch citizens whose presence in the Netherlands has a prehistory going back to the Atlantic slave trade is some 300,000; probably half of the Surinamese Dutch are of Asian origins. ${ }^{3}$

Colonial history has literally come home with these successive waves of post-colonial migration. The post-colonial presence became immediately 
evident in demographics, but more recently also in debates on Dutch identity and culture. Just as in other countries of the 'old' Europe, progressive European unification and large-scale immigration have provoked new, often fierce debates on national identity and the extent to which immigrants can and should adhere to 'national' traditions and values. By conventional Dutch standards, these debates have been unusually heated, hovering between the two extremes of conservative essentialism and unconditional praise of multiculturalism.

The rise of a post-colonial community of one million in the Netherlands has had an unmistakable and in some ways salutary impact on the Dutch debates on national identity. The colonial antecedents of Dutch history have been more strongly and critically incorporated in the national narrative than ever before. Post-colonial identity politics certainly played a role here. 'History', implying an imputed Dutch collective guilt handed down through the generations, was used as a strong argument, particularly by leaders of post-colonial migrant communities. The Dutch government responded accordingly in the past decades, supporting and subsidising commemorations, statues and museums, research projects and the like for post-colonial migrant communities.

In all of this, we witness present governments acknowledging responsibility for - from a contemporary perspective - morally dubious or outright immoral state actions going back decades and even centuries. Perhaps seeking some kind of moral redemption, but also trying to enhance social cohesion, the state answers to the urges of its post-colonial citizenry. This does not necessarily lead to consistent rewritings of the past. The Dutch East India Company (the Vereenigde Oost-Indische Compagnie in Dutch, VOC) is celebrated while shame and remorse dominate the memory of the Dutch West India Company (Geoctroyeerde West-Indische Compagnie in Dutch, WIC). This contrast has something to do with the different trajectories of the two companies, but arguably as much or more with the willingness to respond to post-colonial migrants' divergent ideas about these pasts.

Whatever the inconsistencies and moral challenges, the 'repatriation' of post-colonial migrants has had the effect of bringing colonial history back into the canonical version of national history. This is best illustrated in the recently coded canonical version of Dutch history defined by a government commission and subsequently accepted as the model for primary and early secondary school history education. The new canon, available online (www.entoen.nu) testifies to an enhanced awareness of the significance of colonialism in and for Dutch history. Of the 50 'windows' comprising Dutch history, five are exclusively about colonial history, while several other windows have a colonial dimension. Nowhere do we come across glorification of colonialism, the perspectives varying from neutral to explicitly critical. 
Once we move to renderings of colonialism outside of academia, the picture becomes more blurred and one encounters more self-congratulatory perspectives on colonialism. Dutch colonialism in Asia evokes mixed memories, while the Dutch Caribbean history is mainly equated with slavery and therefore shame. This lack of balance reflects the contemporary framework in which colonial history is reinserted in the national narrative. There is a geopolitical context in which the Netherlands prides itself of having been among the pioneers of globalisation, but expresses embarrassment regarding colonialism as such and, in particular, as to its excesses. This intermingles with a domestic context in which post-colonial migrant communities demand that their voices be heard in the new narrative of Dutch national history.

In all of these debates, we may observe that leaders of post-colonial migrant communities have successfully capitalised on shared history. This need not necessarily mean claiming older and priority rights to full citizenship over and above the other ethnic minorities in the country, but at times precisely that implication is voiced. Cultural affinity then becomes an additional argument. In order words, as a late vengeance, references to colonialism become forceful arguments for full and undisputed contemporary citizenship.

The Atlantic slave trade and slavery in the Caribbean colonies are increasingly singled out as the nadir of colonial history. In 2000, 7 per cent of a representative sample of Dutch citizens indicated that among all episodes of Dutch history commending shame, the Dutch participation in the slave trade was at the top of their list of embarrassment. Four years later, this proportion had increased to 16 per cent. By 2008, this was up to 24 per cent, making the Dutch participation in the slave trade the answer most frequently given to this question. No other episode in Dutch history elicits more embarrassment (De Geschiedeniskrant 26 March 2008).

The pendulum continues to swing though. The VOC celebrations continued in spite of widespread irritation in countries implicated with the company such as Indonesia, India and South Africa, and well-publicised criticism by Dutch scholars. A backlash regarding official Dutch remorse about the WIC and Atlantic slave trade is not altogether unthinkable either. There has been no shortage of radical xenophobic websites denouncing monuments and remorse for slavery as nonsensical. Shortly before he was murdered in 2002, populist right-wing political leader Pim Fortuyn accepted the facts of Dutch involvement in the Atlantic slave trade, but ridiculed inherited guilt and reparation claims. In 2005, one of his later and most successful epigones, Rita Verdonk, then a member of cabinet, made a highly disputed official representation at the annual Emancipation Day celebrations in Amsterdam. But by 2008, launching her new political movement 'Trots op Nederland' ('Proud of the Netherlands'), she complained that 'everywhere in the Netherlands, monuments for slavery are erected 
[that] depict our culture as awful'. One may well assume she anticipated many potential Dutch voters would support this firm stance (Fortuyn 2002: $158)^{4}$

\subsection{Slave trade and slavery in the East and West Indies}

We may well assume that the respondents' shame about the Dutch involvement in slave trade and slavery was exclusively linked to the Atlantic system. The Dutch involvement with slave trade in the Indian Ocean and colonial slavery in the territory covered by the VOC has received only slight scholarly interest and no public interest at all. This is actually one of the reasons the quadricentennial of the VOC establishment could be extensively celebrated in the Netherlands, an act unthinkable for the WIC (Oostindie 2003: 153).

Slave trades and slavery in the Dutch East and West Indies were two circuits that functioned virtually independent of one another, but lend themselves very well for comparison. This includes the scale and organisation of the slave trade, number and origin of the slaves, their economic importance to the colonies, contrasts between indigenous and foreign slavery, slavery regimes, inter-ethnic relations, creolisation and local cultural formation and, finally, abolition and emancipation.

Several conclusions may be drawn from recent tentative research, particularly the work of Vink (2003) and Van Welie (2008). First, the numbers game. The Dutch role in the Atlantic slave trade has long been established. Over the centuries, Dutch slavers were minor players, embarking some 555,000 or 5 per cent of the 12.5 million enslaved Africans destined for the 'middle passage' across the Atlantic. In the seventeenth and early eighteenth centuries, however, the share of the Dutch was more prominent and they were also instrumental in exporting the sugar-and-slavery model from Brazil to the Caribbean.

Whereas the Dutch slave trade is mostly thought of as an Atlantic phenomenon, historians have long known that the VOC also engaged in slave trade. In a pioneering article, Vink (2003) suggested that the Dutch Indian Ocean slave trade was actually more voluminous than it was in the Atlantic. Van Welie's discussion of the literature and evidence makes it clear that the methodological and conceptual issues are far more complicated for the Asian slave trades than for the Atlantic area. Even short of satisfactory quantitative series, we may confidently say that in the East, too, the Dutch were active and unscrupulous buyers of slaves - in the realm of the VOC, enslaved Asians and, to a lesser degree, Africans supplied by local traders. The Dutch partners in oceanic trade were Asians, particularly Chinese and also Africans. 
Up to the abolition of slavery (1863 in the Dutch case), slave labour formed the backbone of the colonies in the Americas - slave-produced tropical produce was the raison d'être of these colonies. Dutch Brazil and, even more, the Guyanas were typical plantation economies, with enslaved Africans making up a massive majority of the population. Conversely, in most of the Asian settlements and colonies, slave labour was mainly urban and incidental to other forms of locally procured labour, whether bonded or not. Slaves formed a tiny minority in the overall population of the Asian colonies. Only in places such as Batavia, Banda and Ambon did they make up half the population by the late seventeenth century and hence had a more significant impact.

Much has been written on the absence of a serious abolitionist movement in the Netherlands regarding the Atlantic slave trade and slavery. Drescher (1994) presented the classic analysis of the Dutch paradox over two decades ago. Clearly, this lack of abolitionist fervour is not that atypical in a European, let alone global, context. Yet, it contrasts strongly with the exceptional British case and also with nationally cherished ideas about Dutch progressiveness and humanitarianism. Studies on slave owners' attitudes in the Dutch Caribbean only confirm this sobering observation. Again, the study of Dutch attitudes towards enslavement in Asia is only in its infancy. There is no indication, however, that Dutch colonialism has a more commendable record here. Perhaps it was even easier to conceive of slavery as self-evident in Asia than in the Americas. In Asia, the Dutch, like other Europeans, simply participated in pre-colonial networks of slave trade and Europeans were certainly not exceptional in their deployment of slaves. ${ }^{5}$

Historians are generally weary about generalisations regarding slavery's variants of 'mild' versus 'harsh', even more so when such variations are explained through reference to criteria such as the national or cultural backgrounds of slave owners. Wherever there is slavery, abuse is endemic; so is slave resistance. Nonetheless, we may possibly discern some contrasts between the practice of slavery in the Dutch Atlantic and Dutch Asia. For all we know, for most enslaved, slavery in Asia would imply urban and domestic rather than agro-industrial labour, was more gender-balanced and implied lesser racial and ethnic distinctions. As a consequence, manumission was far more common, as was the likeliness that the descendants of manumitted slaves would be fully incorporated in the wider society, not necessarily in the lower classes. For most Asian slaves, there was no such thing as the dreaded middle passage, and probably lesser racial stigmatisation and alienation.

While this hypothesis awaits scholarly scrutiny, it is useful for present purposes to highlight another dimension of the history of slavery. Throughout the Americas as well as in the Afro-Caribbean diaspora in Europe, the Atlantic slave trade and New World slavery are crucial to the 
way descendants of these enslaved Africans think of themselves, colonial history and contemporary issues ranging from racism to achievement. Conversely, their visible African ancestry makes them victims of this history identifiable to all. Slavery, in a sense, has remained, or has become a central feature in Afro-American identity.

Nothing of this sort applies to the former Dutch colonies in Asia. Remember that slavery was not nearly as dominant in the Asian territories as it was in the Americas. Moreover, it is difficult to point at legacies of slavery or at descendants of slaves - and where this is possible, in Indonesia, one would more likely be dealing with traces of the indigenous slavery that both preceded and outlasted colonial slavery. In other words, whereas colonial history itself does not have the contemporary weight in Asia that it has in the Caribbean, slavery evokes even less living memories. ${ }^{6}$

\subsection{Commemorating Atlantic slavery: Gestures and dissonance}

For all practical purposes, the 'Dutch' memory of slavery is narrowed down to - in this order - Surinam, the Antilles and perhaps Africa, symbolised by the Elmina fortress in Ghana. The Dutch involvement with slavery in the domain of the VOC has been largely forgotten. The same, incidentally, applies to enslavement of Dutch citizens in Northern Africa in the early modern period. The rediscovery of slavery in Dutch history is therefore partial and corresponds to a particular demand in Dutch society expressed mainly by the Afro-Caribbean community.

Since the late 1990s, Dutch government and institutions in the public arena have been forthcoming in financing and otherwise supporting initiatives to commemorate Atlantic slavery. In the presence of the Dutch queen and prime minister, a national commemorative monument was inaugurated in Amsterdam on Emancipation Day, 1 July 2002. The Nationaal Instituut Nederlands Slavernijverleden en Erfenis (National Institute for the Study and Documentation of Slavery and its Legacy, NINSEE), was established one year later in Amsterdam. Zeeland, once the major slave trade province, followed suit in 2005 with its own monument, in Middelburg. In 2006, the beautiful, early 17th-century mansion of the Amsterdam mayor was nailed with a plaque indicating that one of its first inhabitants was an official of the WIC with a special assignment of the Atlantic slave trade.

Invariably, such inaugurations went accompanied with solemn declarations. Members of the Dutch cabinet expressed 'deep remorse', as did the future Dutch king, on a visit to Ghana. Cultural institutions financed by the Dutch state embarked on a wide variety of initiatives, ranging from the publication of books, through the creation of genealogical databases at the national archives and restoration projects, to a series of exhibitions in 
various museums and documentaries aimed at school children. Media coverage was extensive and helped raise public awareness on the issue - possibly triggering the later chauvinistic backlash as well.

There is irony, perhaps bitter irony, in the fact that the initiative in all of this was definitely metropolitan, with Surinam and the Antilles obtaining second servings most of the time. The successful Caribbean lobby in the Netherlands to 'unsilence' the slavery past has inadvertently served to strengthen the metropolitan hold on the digestion of colonial history. Of course 'metropolitan' now includes views and players from the Caribbean community but, even so, the historical asymmetry continues to be reproduced.

Within the Netherlands, the urge to accept Atlantic slavery as part and parcel of Dutch history may have been spectacularly successful, but this does not mean that there is no dissonance. There is an at times heated debate about that. In a recent analysis of the debates, Dutch historian Van Stipriaan has made a telling distinction between 'white' and 'black' perspectives. His argument is well worth quoting at some length. He characterises the 'black' discourse as subaltern, Afro-centric, anti-colonial and inspired by US debates on slavery as the Black Holocaust and hence the claim to reparations. The 'white' discourse, in his perspective, is 'not white of an intrinsically racist character' and actually even anti-racist, but topdown, paternalistic, a product of the political, cultural and scholarly establishment. Van Stipriaan, himself a white, well-established historian with strong links to the Caribbean communities, thinks of himself as one of the few 'desperately' trying to build bridges between the two [discourses]' (Van Stipriaan 2006: 169).

There is a point in this distinction. At the turn of the millennium, the Dutch establishment engaged with a certain eagerness to the challenge to 'do good', to speak out against moral flaws of the nation in a distant past, to present conciliatory gestures. The new-found consistency was often summarised in affirmations to the effect that there was a hideous inconsistency in thinking of the Dutch Golden Age of economic and political ascendancy, religious and philosophical toleration and Rembrandt without also acknowledging this period as the starting period of the nation's involvement in the Atlantic slave trade. So initially, there was something of a feel-good dimension to all of this, coupled with political considerations akin to the multiculturalism paradigm and the accompanying commitment to inclusionary politics, as in the broadening of the narrative of the nation.

It soon turned out that there were more radical expectations within the Caribbean community. Anyone engaged in debates on the issue of slavery and its contemporary legacies was soon bound to be caught in heated debates on legitimacy, black-versus-white perspectives and eventually the question of apologies and reparations. Liberal white historians, operating within a reconciliatory mode, could easily find themselves exposed to 
criticism of high-jacking a 'black' issue or, at best, of realising that their contributions were met with distrust and, at times, overt hostility by radical Afro-Caribbean protagonists.

Van Stipriaan encapsulates this well - even if perhaps not particularly encouraging to the present author - in his comments on two books edited for the Prince Claus Fund in 1999 and 2001. The first, in Dutch, made a chapter case for commemoration and a monument in the Netherlands, while the second, in English, provided a broader comparative context.

These books have certainly influenced debates within the white discourse. Within the Black discourse they have played no role whatsoever in the Netherlands, with the exception that the editor of both books, Oostindie, is considered as belonging to 'them'. (Van Stipriaan 2006: 168 referring to Oostindie 1999 and Oostindie 2001)

This probably correct observation begs many questions. The first issue seems of a conceptual nature, but has a wider epistemological significance. Much of Van Stipriaan's 'white discourse' actually refers to the field of academia, the terrain of white as well as, indeed, a minority of black historians. Much of his 'black discourse', by contrast, is about grass roots feelings, memories and wisdoms that operate at an altogether different level. Within academia, there is, by definition, room for dissonance based on argumentation. In the field of the humanities, there is also a growing awareness of the significance and inevitability of multivocality. Yet it seems a risky - and to the present writer, in the end untenable - position to juxtapose two fundamentally different types of discourse as somehow of a same nature. After all, scholarship has higher claims than providing 'just another perspective' on, say, the origins of mankind, the treatment of cancer, quantum mechanics or the historical phenomenon of slavery. For that reason, we may well accept the fact that some feel there is a 'white discourse' out there that does not answer their needs in remembering slavery and pondering its legacies. But accepting that fact does not imply that scholarship need apologize for its own methods and epistemological claims.

While this argument leads to a rejection of the scholarly validity of the black-white dichotomy, there is also a sobering strategic concern. The same representative sample who ranked Dutch slave trade and slavery as the most shameful episode in national history demonstrated little sympathy for reparations (De Geschiedeniskrant 26 March 2008). More broadly, the growing popularity of right-wing populism in Dutch society and politics suggests that the room for a radical 'black discourse' to reach any broad backing seems slight. Wide disenchantment with the multiculturalism paradigm actually means that the liberal 'white discourse' itself is at the 
defence. It might be wise therefore to think again about thinking of the differences between these two perspectives as crucial - there is another white world out there with little patience for either of Van Stipriaan's perspectives. This, incidentally, is one reason some influential African American intellectuals will not have anything to do with the reparations claim, feeling that it will only backfire on more moderate accomplishments in the civil rights movement (Torpey 2006: 122-123, 127).

Next, there are the questions about to what extent a professional historian should engage in this type of considerations in the first place and how a historian can relate to the fashionable cultural studies' concept of multivocality in this context. Both questions will be addressed below. But first some of the contents of the black-versus-white controversy in Dutch politics should be discussed. From this short survey, it will become clear that, as Van Stipriaan rightly observes, the 'white' perspective defines a good deal of the Caribbean participants as well - which again raises the question of whether this bipolar terminology is analytically helpful rather than confusing.

What have been the issues at stake? A good introduction is provided in a book co-authored by Van Stipriaan, Heilbron, Bijnaar and Smeulders, all linked in some way to NINSEE. In Op zoek naar de stilte ('In search of the silence'), as the title indicates, the authors - three of Caribbean origins - assume that Dutch involvement in the Atlantic slave trade and slavery itself has been intentionally put to rest ever since emancipation. The book intends to disclose hidden or forgotten legacies of this history in the Netherlands itself. Their tour brings us to museums that never before gave the black servants in their master paintings much thought; to archives and libraries containing a wealth of data, interpretations, ideals and prejudice; to associations and institutions claiming to operate from a genuine African diaspora perspective; to specialists in oral history and oral traditions referring to the slavery period; to participants in debates about legacies and trauma and so on (Van Stipriaan, Heilbron, Bijnaar \& Smeulders 2007).

Op zoek naar de stilte offers many perspectives and certainly the firstever attempt to provide a broader perspective on the ways slavery is or is not remembered in the Netherlands. The book confirms the perhaps sad but, after all, rather obvious conclusion that the slavery past has far more significance to descendants of once enslaved Africans than to white Dutch citizens and makes the normative point that this history should be accepted as a shared past for all Dutch people - this is of course fully in line with the liberal progressive politics that led the Dutch government to create a national monument and NINSEE in the first place.

New, refreshing but at times also worrying is the extensive discussion of the wide divergence in the way Dutch people of various backgrounds think about slavery and its legacies. Not surprisingly, much of what $O p$ zoek naar de stilte details here concurs with Van Stipriaan's analysis of a divide 
between white and black discourse. Extreme Afro-Centric positions are cited, e.g. the affirmation that white historians cannot possibly write a reliable history of slavery: 'You don't ask Nazis to write the history of the concentration camps either!' (e.g. Van Stipriaan et al. 2007: 121). But perhaps the more important observation is that within the Afro-Caribbean community in the Netherlands, too, there is a wide variety of ideas about slavery and its legacies.

What are these contestations all about? To start with, there are disputes about the legitimacy of intellectual and organisational leadership. Since the 1990s, a series of grass roots groups has been involved in the debate about slavery and the urge to recognise this past as integral to Dutch history. Dutch government recognition of the validity of these claims resulted in institutionalisation and a long series of projects entailing black and white cooperation and bridging. What transpires from $O p$ zoek naar de stilte is that most participants value the results so far with a mix of satisfaction and uneasiness, but equally that there is dissonance within the Afro-Caribbean community. Thus, some radical grass-roots organisations perceive of national institutions now put in place, NINSEE, in particular, as too moderate.

What, then, is moderation? Which approaches generally banned from the 'white discourse' seem to be eschewed by NINSEE as well? Basically, these refer to concepts and approaches derived from radical African American discourse, such as the terminology of the Black Holocaust, the discourse of dehumanisation and cultural trauma, the insistence on formal Dutch apologies, more reparations and so on. Anyone following NINSEE over its first five years of existence will have perceived a delicate balancing act between responding to the claims of the more radical elements in its Afro constituency and fulfilling its bridging mission towards a wider and, after all, predominantly white society. That act was not always consistent or successful, but bearing in mind NINSEE's conflicting positions, it could hardly have been otherwise.

\subsection{Black Atlantic orientations and the concept of cultural trauma}

The Dutch 'rediscovery' of Atlantic slavery is part of a wider trend in Europe and the Americas and testifies to the impact of the Black Atlantic. Not all countries with a slavery past have responded in the same way to claims for recognition. Within Europe, France, the Netherlands and the United Kingdom have been more responsive and self-critical than Portugal or Spain, a difference that may be accounted for by divergent cultural and political traditions and certainly by reference to the dissimilar volume and political clout of metropolitan Afro communities. 
Debates and claims regarding slavery and its legacies have increasingly become framed in a seemingly delocalised transnational discourse that, at the end of the day, discloses a heavy predilection for radical African American perspectives grounded in US realities. At times, then, supposedly broad African diasporic conceptualisations might well be a mere transplanting of American ideas and realities to other contexts. This skipping over past and present differences in time and place is not necessarily useful to understand either the realities of slavery nor to weigh its contemporary legacies. Again, some examples from the Dutch debates may illustrate this point.

Terminology is an obvious illustration of American derivation, as seen in the use of the conceptually disputable and politically provocative notion of the Black Holocaust. The claim of 'reparations' is another idea inspired by US debates. These are appropriations one can appreciate or not, but there is no reason to propose these American concepts be less (or more) appropriate in a European - or, for that matter, Caribbean or Latin American - context. But once we read about black-versus-white perspectives, about a white 'silencing' of the past or about generalised legacies of slavery, historians should make amends.

American interpretations of slavery and its legacies are rooted in a unique historical experience with unique implications for race relations. Perhaps inevitably, the stark racial divide characterising US society both during and after slavery translated in strongly oppositional understandings of slavery and its legacies. Hence, the emergence and popularity of the idea of mutually irreconcilable perspectives, grounded in a long history of brutal suppression and cultural resistance, proudly celebrated by the civil rights' movement and given new credential by cultural studies' insistence on the inevitability and, indeed, legitimacy of partial truths and emic discourse.

Yet any historian of the Americas will appreciate that the US record of slavery and post-slavery and race relations is only one out of many models, a uniquely grim bipolar model at that. Throughout Latin America and even in the non-Spanish Caribbean, society and race relations during slavery and certainly after emancipation were not necessarily less violent, but certainly more fluid and ended up producing societies that defy the notion of bipolarity. To be sure, there was and has remained a class-cum-colour social hierarchy, persistent racism and so on. But it simply does not make sense to think of these societies and how its citizens think of themselves primarily in terms of 'race' and a black-versus-white polarity.

Narrowing understandings of slavery and its legacies to a simple division in a black-versus-white discourse therefore misses much of the complexities of the wider Afro-American experience. This should worry not just historians, but anyone engaged in the debate on the contemporary relevance of slavery. How, for instance, are we to understand the concept of 
'silencing the past' itself? The idea gained currency with Trouillot's seminal book, Silencing the past. Trouillot's argument is straightforward. There are hegemonic versions of history that tend to actively silence subaltern voices. He applies this paradigm specifically to the 'unremembering' of the Haitian Revolution and the quincentenary of Columbus' 'discovery' of the New World (Trouillot 1995).

Seen from this perspective, one understands the popularity of the recurring trope of 'unsilencing' the slavery past - and indeed the title of $O p$ zoek naar de stilte. The big question, however, is whether it really makes sense to always think of this kind of silence as engineered, as actively imposed by hegemonic forces. If one US plantation mansion converted into a museum tells a wondrous story about the antebellum Deep South while skipping over the harsh realities of slavery, yes, then the conclusion of silencing seems astute (Eichstedt \& Small 2002). But how much credence can we give the idea of a determined political project of silencing the Dutch slavery past without taking into account that, unlike the Americas, there were hardly any slaves in the metropolis during slavery or AfroCaribbean migrants afterwards and, subsequently, hardly any pre-1970s exposure to this grim and shameful history and its migratory aftermath? Or, from another angle, should we then also conclude that the persistent neglect of the Dutch participation in Asian slave trade and slavery is another instance of deliberate silencing - and, if so, by what hegemonic power and why?

In the Dutch debates, as elsewhere, dehumanisation and cultural trauma are recurrent concepts in the debate about slavery. Anyone familiar with travelogues, planters' manuals and abolitionist writings from the slavery period will recognise the idea of dehumanisation (see Davis 2006). This idea of dehumanisation has found its contemporary translation in the idea of cultural trauma (e.g. Alexander 2004; Eyerman 2001). This trauma, in turn, is sometimes advanced to explain psychological problems such as low self-esteem, underachievement and deviance. The very idea of cultural trauma and its consequences is fiercely debated, and it makes little sense to discern between a black trauma versus a white discourse in this respect - if only because another, often overlapping black discourse emphasises precisely the agency and resistance of enslaved Africans and their descendants.

Yet, it may be worthwhile to consider again how this trauma metaphor works out in the Dutch debates and how the arguments relate to empirical research (for a more extensive discussion, see Oostindie 2008c: especially 14-18). First, let us look at the concept of cultural trauma itself, which refers to a collective memory of a shocking formative period transmitted over several generations to the point that this memory becomes crucial to group identity. Trauma in this context refers not only, and perhaps not even primarily, to the dehumanising experience of slavery itself, but also and 
perhaps more to the internalisation of racism and the deep disillusions of the post-slavery period. Trauma, the argument runs, inhibited the descendants to fully exploit the chances presented by freedom, and initiated a vicious and as yet unbroken circle of feelings of inferiority, lack of initiative and irresponsible behaviour.

The reasoning is not new. Contemporaries observed that European colonial slavery dehumanised the enslaved (as well the enslavers). This reasoning found its way to modern historiography in concepts such as 'dehumanisation' and 'traumatisation'. In political debates, this way of thinking is expressed in the thesis of internalised racism and self-victimisation. One line of argumentation emphasises the narrow limits of post-emancipation freedom and, hence, the imposition of marginality. The other, not necessarily opposing perspective, stresses internalisation of racism, resulting in low self-esteem and unconsciously chosen victimhood and hence irresponsible behaviour.

This approach is also discernible in debates on the legacies of slavery in the Dutch orbit, emic as well as etic. Such debates require precision, empathy and, among the descendants, the courage to speak out about delicate emotions. Yet, it remains problematic that the references to trauma remain speculative and ill-defined. We have no way of establishing what proportion of the descendants of enslaved Africans feels victimised in which ways and degrees, conscious or unconscious - individual suffering does not equal collective trauma. Moreover, the possible relation between 'trauma' and real-life behaviour is speculative. One should also wonder whether possible feelings of victimhood are eventually rooted in the period of slavery or rather in the subsequent period.

Such objections need to be taken serious. The contemporary template of Caribbean - and, to a lesser extent, Latin American - slavery bears the strong imprint of the US hegemony in Atlantic studies. Local specificity is often absent. But New World slavery was not uniform and neither was post-emancipation history, so we should not expect similar contemporary outcomes. Historical scrutiny, therefore, is crucial.

Indeed, most of the historiography of the last decades emphasises the vitality and agency of the enslaved, ranging from open and covert resistance to cultural creativity - and, hence, implicitly undermines the idea of collective trauma under slavery. The more or less hegemonic contemporary paradigm holds that no matter how repressive and alienating slavery in the Americas may have been, it did not really dehumanise its victims. Moreover, there were significant regional and longitudinal variants in Atlantic slavery. The lives of New World slaves were enacted between the extremes of subjugation and resistance. The seemingly outdated concept of 'accommodation', utilised in the study of foreign occupations, prisons and even concentration camps, is still a useful analytical tool. One crucial 
contrast is that Caribbean slaves over time struggled to obtain more degrees of freedom, more autonomy within enslavement.

Two more comments on the idea of slavery trauma seem appropriate. The first relates to identity politics and political opportunity structures. Recent research on collective or cultural trauma stresses the processes in which past occurrences are or are not transformed into collective contemporary trauma. The emphasis on distinction is crucial. Not all communities define past suffering as traumatic, nor do all societies tolerate and/or support signifying institutions. This implies that not only the recognition, but the very existence, of collective trauma depends to a large extent on choice, both by descendants of past victims and the societies they inhabit.

A second comment refers to the issue of transgenerational transmission of trauma. Recent research of victims of traumatic events - in particular, survivors of the Holocaust - suggests a remarkable and successful determination among the majority to shield their children from their own trauma (Sagi-Schwartz, Abraham, M.H. van IJzendoorn, K.E. Grossmann, T. Joels, K. Grossmann, M. Scharf, N. Koren-Karie \& S. Alkalay 2003; M.H. van IJzendoorn, M.J. Bakermans-Kranenburg \& A. Sagi-Schwartz 2003). There seems to be no good reason to assume that Africans and their descendants, many generations away from the traumas of the middle passage and slavery, would think and act otherwise - perhaps the frustrations which led to the cultural trauma paradigm lie primarily in the present?

It is exceedingly difficult to answer such questions. Suffice it to conclude here that there is no scholarly substantiation - or refutation, for that matter - of the idea of transgenerationally transmitted slavery trauma and that explanations for contemporary behaviour referring to cultural trauma lack empirical substantiation and precision.

\subsection{Slavery trauma in the Dutch orbit}

The above section should be understood as a plea for analytical transparency and nuance rather than as an a priori refutation of the idea of slavery trauma. What we need is rigour alongside empathy, as well as an understanding of local specificities, then and now. This point may be illustrated by a brief discussion of three 'Dutch Caribbean' debates in which trauma is often evoked (Oostindie 2008c: especially 17-18).

The concept of internalised racism is neither new nor far-fetched. Centuries of exposure to racism left deep scars among the descendants of enslaved Africans, no matter how often white Dutch might have ridiculed or denied this. The challenge of mental redemption has been expressed by countless Afro-American leaders, intellectuals and artists. Inspired by the Haitian Revolution, the enslaved African Tula led a major slave revolt on Curaçao in 1795, arguing that all men are equal and entitled to live as 
such. Some 70 years ago, the Surinamese activist and writer Anton de Kom criticised the 'slave mentality' of his compatriots. One still finds obsessions about blackness and 'improving' one's colour throughout the Black Atlantic decades after the 'Black is beautiful' concept was coined and Bob Marley's famous 'Redemption song' urged: 'Emancipate yourself from mental slavery/None but ourselves can free our minds.'

Ignoring such cultural legacies is at once pointless and demonstrates a lack of respect. But it remains an altogether different question whether such individual frustrations and pain should really be understood as collective trauma. Perhaps historians cannot bring much light to this debate. But serious historical research will underline once more the crucial distinctions of time and place. Just as New World slavery had many variants, so did race relations during and after slavery. This much is confirmed by decades of comparative research. Hence, the hypothesis that the evident historical variation resulted in divergent contemporary psychological legacies of slavery in the African diaspora. The historically unique case of US race relations should not be taken as a generalised Atlantic model for either history or its contemporary political and psychological legacies.

Next we turn to the oft-cited causal relation between slavery, trauma and deviant behaviour. Over the past decades, some 40 per cent of the total Curaçaoan population has settled in the Netherlands. A small but disproportional share of this group engages in often violent criminal behaviour. Frequently, the behaviour is explained with reference to slavery - much as it was before in debates about high rates of deviance among lower-class Afro-Surinamese or indeed of youth on Curaçao itself. Key terms in the discourse are low self-esteem, poor social and linguistic skills, macho behaviour, a culture of shame, failing socialisation and, in particular, matrifocality with its related images of teenage mothers and absent fathers. The link to slavery is easily made. Thus, some years ago the official representative body of Antilleans in the Netherlands known as the Overlegorgaan Caraïbische Nederlanders (OCAN) held a conference on what was referred to as 'collective trauma derived from the slavery past'. The 'slavery trauma' was defined among Antilleans as an 'unhealed - and unshared - psychic wound that is transmitted through the generations and makes victims into perpetrators', with potentially significant consequences 'for mutual trust, self image and self-confidence, family life or child-rearing'. At the same time, the report emphasises that many disadvantaged Afro-Caribbean people 'manage to liberate themselves from a subculture of poverty and collective trauma (OCAN 2006: 11). Again, this type of 'explanation' lacks precision. There was and is a broad variety of practices in kinship and upbringing, both during and after slavery in different parts of Afro-America. Dutch Caribbean slavery respected the integrity of slave families far more than was the case in the US. Moreover, matrifocality need not result in a deficient childhood and education. Part of the contemporary problems with 
Curaçaoan youth derive not from the distant past, but from recent developments: the exodus to the Netherlands and the resulting destruction of previously functioning family networks. In addition, the external factors of geography and globalisation dictated the emergence of narco-trafficking as a hugely profitable crime-generating sector on the island and in the Netherlands. Curaçaoans are indeed disproportionately active in this sector, but slavery trauma provides no hard explanation in this respect and matrifocality based in slavery provides, at best, a remotely partial one. Undue emphasis on an alleged chain of causality that linked slavery in the Caribbean to integration problems in the Netherlands reminds one of Bosma's remarks in his introduction to this book on a 'culture of victimhood'.

Finally, what about the relevance of slavery and its legacies in contemporary debates about decolonisation and politics? Surely, the determination to part with a metropolis once responsible for slavery has been a strong element in Caribbean nationalist discourse - indeed, Surinamese political nationalism is a point in case. Yet the use of 'slavery' in debates about politics and, in particular, about the present constitutional status of the Dutch Antillean islands seems unproductive.

Unlike Surinam, the six Dutch Antillean islands have adamantly refused the Dutch 'gift' of sovereignty. The Hague's policy of bringing the federation of six to an early independence failed on both accounts: sovereignty is refused and cannot be imposed, and the six have managed to convince the Dutch to allow for the dismantlement of the Antilles-of-six. In different forms, all will end up having separate constitutional and governance links to the metropolis. The Hague has embarked on a course of strong involvement in local governance leading to Antillean resentment against 'recolonisation', but also internal dissent (Oostindie \& Klinkers 2003; Oostindie 2008a.)

In the fiery debates on these issues, some protagonists at times invoke the issue of slavery. This seems not particularly helpful. The debates on the constitutional future needs another type of argument, an awareness of geopolitical context and small scale. Antilleans have good reasons to hold on to the metropolitan lifeline. Some feel this testifies to a slave mentality. It seems more appropriate to underline that this policy to minimise risk characterises all non-sovereign territories, wherever in the world and whether or not their past is scarred by slavery.

This is the crucial point in the Antillean debates as well. Support for independence is negligible. The bone of contention is really how much Dutch involvement is acceptable. In these debates one finds much anticolonial rhetoric and references to slavery, but the political choices will remain pragmatic. As the Dutch will not find themselves able to withdraw from the Caribbean, Antilleans will continue to pick the fruits of their enslaved African forebears' victimisation: materially sweet fruits, psycho- 
logically perhaps more bitter ones. No doubt bitterness will continue to inspire post-colonial anger and understandable albeit not very productive references to the horrors of slavery.

\subsection{Historians and the legacies of slavery}

In their highly entertaining book Why truth matters (2006), the philosophers Benson and Stangroom advocate scholarly rigour and intersubjectivity against postmodernist cultural studies' and other paradigms questioning the epistemological legitimacy of scholarly claims to uncover 'truth'. One argument against relativism exposed in the opening pages of the book is worth quoting in full.

There are true facts about, for instance, how many people were murdered in horrible terrifying degrading circumstances in any one of history's many instances of massacres, war crimes and ethnic cleansings. (Benson \& Stangroom 2006: 1)

No serious scholar of slavery could object to this statement, but it is as legitimate to engage in debates about the total volume of the Atlantic slave trade as it is to wonder aloud whether or how this particular trade is unique in world history, whether it should be classified among 'massacres, war crimes and ethnic cleansings', perhaps even as a Black Holocaust, or rather as something altogether different. Scholars should feel free to ask these and many other sensitive questions and should not be unduly concerned by questions of black-versus-white perspectives. And yet, in dealing with the issues of slavery, legacies and racism, no historian can ignore ethical and political sensitivities - and certainly, as Bosma points out in this book's introduction, no historian can circumvent the uneasiness of remaining 'pockets of silence' in a post-colonial world.

In this context, it is useful to return briefly to Van Stipriaan's reviews of the debate in the Netherlands and particularly the problematic distinction between 'white' and 'black' discourse. These two 'discourses' may cover much of the debate in Dutch Caribbean circles, but certainly not the entire spectrum in Dutch society, where leading populist politicians state that even the liberal 'white' discourse suffers from political correctness and unwarranted antinationalist sentiment. For historians, the more pressing question is how to prevent the study of slavery and its legacies from becoming divided in such closed compartments. Serious scholarship can and should defend itself against the idea of being 'just another discourse'. Much has been made in recent decades about 'multivocality'. Yet, while every serious scholar should allow for the fact that people experience and remember all sort of things differently today than in the past, a radical 
reduction of interpretations to a priori positions or perspectives is no serious scholarly alternative to the comparative historical method.

\section{Notes}

I An earlier version of this chapter was presented at conferences of the Association of Caribbean Historians (Paramaribo, I2-I6 May 2008) and the Society for MultiEthnic Studies (MESA) (Leiden, 25-28 June 2008). Pieter Emmer and Alex van Stipriaan provided much-appreciated comments on it. The present version was published earlier in a slightly different version in Klooster (2009: 305-327).

2 Emmer (2006); Kardux (2004); Oostindie (2003, 2005b, 200I); Van Stipriaan (200I, 2004, 2006). Much more is written on this issue, but these references are to works in English.

3 The 2004 census presents ambiguous figures. The proportion of Surinamese of Asian origin is 42 per cent (27.4 per cent Hindustani and I4.6 per cent Javanese). At 32.4 per cent (I7.7 per cent Urban Creole and I4.7 per cent Maroon), the proportion of Surinamese of African origins seems much lower, though we have reason to think that the 'Mixed' category (I2.5 per cent) mainly also comprises people of African origins. Other census categories are 'Other' (6.5 per cent, comprising Amerindians, Brazilians, Chinese and Europeans) and 'Unknown' ( 6.6 per cent).

4 The argument in 2005 did not concern Verdonk's opinions about slavery and commemoration - but rather her tough anti-migration policies (speech of Rita Verdonk, Amsterdam, 3 April 2008).

5 For a reprint of the Drescher chapter and a dozen comments providing a comparative perspective on Dutch abolition and emancipation, see Oostindie (1995, I996).

6 Due to space restrictions, the practice and memory of slavery in the former Dutch colonies in Africa is not discussed here (see Oostindie 2005b, 2008b). 